УДК 346.24

DOI https://doi.org/10.32849/2663-5313/2020.12.10

\title{
Олександра Кологойда,
}

докт. юрид. наук,

професор кафедри господарського права та господарського процесу

Інституту права

Київського начіонального університету імені Тараса Шевченка

\section{Олена Черненко,}

канд. юрид. наук

старший науковий співробітник

Науково-дослідного інституту приватного права і підприємництва

імені академіка Ф. Г. Бурчака Начіональної академї̈ правових наук Украйни

\section{ПРАВОВИЙ СТАТУС НЕЗАЛЕЖНИХ ЧЛЕНІВ НАГЛЯДОВИХ РАД ДЕРЖАВНИХ ПІДПРИЕМСТВ}

Стаття присвячена дослідженню питань, пов'язаних із правовим статусом незалежних членів наглядових рад підприємств державного сектора економіки. Доцільність створення наглядової ради як органу контролю, що покликаний захищати інтереси власників компанії, визнана у багатьох краінах світу. Поява наглядових рад серед органів управління державними унітарними підприємствами дає можливість залучати до управління професійних та незалежних фахівців, а ие має підвищити економічні показники діяльності суб'єктів державного сектора економіки.

Інституиійні та кваліфікачійні вимоги до членів та незалежних членів наглядових рад не вимагають наявності в особи, що призначається (обирається) на посаду незалежного илена наглядової ради громадянства України. Іноземні громадяни та особи без громадянства мають право нарівні з громадянами України брати участь у конкурсі, але виключно на посади незалежних членів наглядової ради. Членство в наглядових радах не є державною службою, тому у конкурсному відборі таких осіб мають переважати професійні критерії, такі як освіта, досвід роботи та професійні навички у суб'єктах господарювання корпоративного типу відповідної галузі економіки, а також особисті якості кандидата.

Призначенню іноземиів незалежними членами сприяє відсутність спечіалістів потрібного рівня в Україні та той фактор, що іноземиі більш незалежні від впливу різних політичних сил. Нині іноземиі становлять більшість у наглядових радах державних підприємств. Але призначення до складу наллядових рад іноземних громадян створює ризик та може завдати шкоди національним інтересам України в інформаційній сфері, тому потрібно включити до договору з незалежним членом наглядовоі ради зобов'язання про збереження конфіденційної інформачій та комериійної таємниці та відповідальність за їх розголошення.

Розмір винагороди незалежних членів наглядових рад має визначатись у відсотках від чистого прибутку суб'єкта господарювання за попередній звітний період (рік), оиінки ефективності діяльності наглядової ради в иілому, ї комітетів і кожного члена наглядової ради. При цьому розмір відсотку має залежати від галузі економіки та фінансово-економічного стану суб'єкта господарювання. Максимальний розмір винагороди має бути обмежено законом. Умови договору з незалежним иленом наглядової ради обов'язково повинні містити обмеження щодо компенсаиї витрат, пов'язаних з виконанням його обов'язків.

Ключові слова: державне підприємство, корпоративне управління, наглядова рада, незалежні члени наглядової ради.

Постановка проблеми. Реформування у 2016 році системи управління державними підприємствами зумовило появу в унітарних підприємствах наглядової ради як елемента (органу) дворівневої системи корпоративного управління, традиційно більш характерного для корпоративних підприємств.

Дослідження порядку призначення незалежних членів наглядових рад державних унітарних підприємств та господарських товариств, у статутному капіталі яких більше 50 відсотків акцій (часток) належать державі, $з$ числа осіб, які мають громадянство іноземних держав, та порядку визначення ïx винагороди привертає увагу широкої спільноти не тільки науковців і практиків, але й пересічних громадян і набуло актуальності в аспекті конституційного подання 
48 народних депутатів України щодо відповідності Конституції України (конституційності) окремих положень Господарського кодексу України, Закону України «Про управління об'єктами державної власності» від 21 вересня 2006 року № 185-V зі змінами, вимог до незалежного члена наглядової ради державного унітарного підприємства та господарського товариства, у статутному капіталі якого більше 50 відсотків акцій (часток) належать державі, затверджених постановою Кабінету Міністрів України від 10 березня 2017 року № 142, Порядку визначення та затвердження кандидатур представників держави, які призначаються до наглядових рад державних унітарних підприємств, і тих, які беруть участь у загальних зборах та обираються до наглядових рад господарських товариств, у статутному капіталі яких більше 50 відсотків акцій (часток) належать державі, затвердженого постановою Кабінету Міністрів № 143, яке перебуває в провадженні Конституційного Суду України.

Аналіз останніх досліджень. Дослідженню питань, пов'язаних із формуванням та функціонуванням наглядових рад, присвячені праці таких вчених, як О. М. Вінник, Д. В. Задихайло, А.М. Захарченко, О. Р. Кібенко, І. В. Лукач, Д. І. Погрібний, I. В. Спасибо-Фатєєва, та інших.

Метою наукової статті $\epsilon$ дослідження питань, пов'язаних з правовим статусом незалежних членів наглядових рад підпри॥ ємств державного сектора економіки.

Виклад основного матеріалу. Законом України «Про внесення змін до деяких законодавчих актів України щодо управління об'єктами державної та комунальної власності» від 02.06.2016 р. внесені значні зміни в систему управління унітарними суб'єктами державного та комунального секторів економіки шляхом включення до органів управління згаданих підприємств такого органу, як наглядова рада, яка в межах компетенції, визначеної статутом підприємства та законом, контролює і регулює діяльність керівника підприємства.

Поява наглядових рад серед органів управління державними унітарними підприємствами сприятиме ефективній діяльності таких суб'єктів та впровадженню світових стандартів корпоративного управління, оскільки управління завдяки незалежним членам наглядових рад стає більш відкритим, прозорим, професійним. Впровадження інституту наглядових рад дає можливість залучати до управління професійних та незалежних фахівців, а це має підвищити економічні показники діяльності суб'єктів дер- жавного сектора економіки. Доцільність створення наглядової ради як органу контролю, що покликаний захищати інтереси власників компанії, визнана у багатьох країнах світу.

У корпоративних підприємствах у компетенції наглядової ради виділяють три групи повноважень щодо:

1) контролю за роботою виконавчого органу (укладення від імені товариства контракту з керівником, затвердження умов договорів 3 головою і членами правління, організація і контроль за виконанням рішень загальних зборів та ін.);

2) комунікації 3 акціонерами (розгляд звернень про надання інформації, затвердження проекту порядку денного, включених до нього пропозицій акціонерів, скликання позачергових зборів тощо);

3) вирішення фінансових питань діяльності товариства (визначення основних напрямів діяльності товариства і затвердження його планів, надання згоди на вчинення значних правочинів і правочинів із заінтересованістю, затвердження ринкової вартості майна, обрання аудитора та ін.) [1, c. 178].

Законодавець передбачив, що наглядова рада обов'язково утворюється у державних унітарних підприємствах та в господарських товариствах, у статутному капіталі яких більше 50 відсотків акцій (часток) належать державі, за наявності одного з таких критеріїв:

1) вартість активів державного унітарного підприємства або господарського товариства згідно з даними останньої річної фінансової звітності перевищує 2 млрд. гривень;

2) розмір чистого доходу такого державного унітарного підприємства або господарського товариства згідно з даними останньої річної фінансової звітності перевищує 1,5 млрд. гривень;

3) розмір статутного капіталу новоутвореного державного унітарного підприємства, господарського товариства на дату його утворення перевищує 2 млрд. гривень;

4) кількість акціонерів - власників простих акцій такого господарського товариства становить 10 або більше осіб.

Наглядові ради державних унітарних підприємств формуються з членів, які відібрані на конкурсній основі і делеговані до наглядових рад державою, та незалежних членів, які повинні становити більшість від іiї загального складу, і ними є особи, які насамперед мають бездоганну ділову репутацію.

Після прийняття рішення суб'єктом управління об'єктами державної власності, 
що здійснює функції з управління державним унітарним підприємством, про утворення у державному унітарному підприємстві наглядової ради:

1) затверджуються відповідні зміни до статуту підприємства та положення про принципи формування наглядової ради;

2) затверджуються умови оплати послуг членів наглядової ради у порядку, встановленому законодавством;

3) приймається рішення про проведення конкурсного відбору кандидатів на посади незалежних членів наглядової ради та визначаються рекомендації щодо їхньої кваліфікації, досвіду та неупередженості;

4) визначаються представники держави в наглядовій раді, які мають відповідати вимогам щодо їхньої кваліфікації, досвіду та неупередженості

5) затверджується положення про наглядову раду та їі склад.

Інституційні та кваліфікаційні вимоги до членів та незалежних членів наглядових рад, визначені нормами Закону України «Про управління об'єктами державної власності» та Вимогами до незалежного члена наглядової ради державного унітарного підприємства та господарського товариства, у статутному капіталі якого більше 50 відсотків акцій (часток) належать державі, затвердженими постановою Кабінету Міністрів України від 10 березня 2017 р. № 142, не вимагають наявності в особи, що призначається (обирається) на посаду незалежного члена наглядової ради, громадянства України.

Під час конкурсного відбору передусім враховуються освіта, досвід роботи та професійні навички. Критеріями для призначення/обрання незалежним членом наглядової ради є:

- статус фізичної особи, яка відповідає вимогам стосовно незалежних членів, визначеним Законом України «Про управління об'єктами державної власності», та вимогам до незалежних директорів, визначеним Законом України «Про акціонерні товариства»;

- наявність повної цивільної дієздатності;

- наявність вищої освіти, професійних знань та навичок, досвіду роботи та інших характеристик, необхідних для належного здійснення повноважень члена наглядової ради, що відповідає видам діяльності державного унітарного підприємства та господарського товариства, у статутному капіталі якого більше 50 відсотків акцій (часток) належать державі;

- добропорядність, неупередженість та бездоганна ділова репутація;
- не посідати виборні посади та не бути посадовою особою органів державної влади та/або місцевого самоврядування;

- відсутність непогашеної судимості;

- відповідність іншим вимогам та володіння необхідними компетенціями, визначеними комісією 3 конкурсного відбору кандидатів на посаду незалежного члена наглядової ради державного унітарного підприємства та господарського товариства, у статутному капіталі якого більше 50 відсотків акцій (часток) належать державі, що не можуть відрізнятись від інших вимог та необхідних компетенцій, визначених для представників держави, що призначаються (обираються) до наглядової ради такого підприємства, господарського товариства.

Вважається, що призначенню іноземців незалежними членами сприяє відсутність спеціалістів потрібного рівня в Україні та той фактор, що іноземці більш незалежні від впливу різних політичних сил. Іноземці становлять більшість у наглядових радах державних підприємств, наприклад: 80 \% у НАК «Нафтогаз»; $71 \%$ - в АТ «Укрзалізниці»; $67 \%$ - в АТ «Укрпошта» [2].

Стаття 26 Конституції України, ч. 1 ст. 3 Закону України «Про правовий статус іноземців та осіб без громадянства» від 22 вересня 2011 року закріплюють принцип національного правового режиму для іноземців та осіб без громадянства, що перебувають (проживають) в Україні на законних підставах. Національний правовий режим має загальний (неперсоніфікований) характер. Іноземці користуються тими ж правами і виконують ті ж обов'язки, що й громадяни України. Тобто Конституцією та законами України іноземцям та особам без громадянства гарантуються особисті (громадянські) права, що належать до загальновизнаного переліку природних прав, право володіти, користуватись і розпоряджатися своєю власністю, результатами своєї інтелектуальної, творчої діяльності, здійснювати підприємницьку діяльність тощо.

Водночас дія національного режиму щодо іноземців має певні межі: вони повністю не прирівнюються у правах та обов'язках до громадян України. Загальноприйнятим у науці конституційного права є підхід щодо різного за обсягом прав та свобод конституційно-правового статусу громадян держави та інших категорій осіб, які можуть проживати на території цієї держави (іноземних громадян, осіб без громадянства, біженців).

Більш того, серед умов призначення/ обрання особи на посаду члена наглядової ради відсутня вимога щодо перебування (проживання) в Україні іноземців та осіб 
без громадянства, що дозволяє запрошувати та брати участь у конкурсі на посади незалежних членів наглядових рад особам, які не перебувають (проживають) в Україні. Такі особи не користуються в Україні національним правовим режимом.

При цьому слід враховувати особливості відносин корпоративного управління за участю голови та членів наглядової ради товариства та порядок роботи наглядової ради. Виконання функцій голови або члена наглядової ради не вимагає постійного перебування (проживання) в Україні. Засідання наглядової ради проводяться в міру необхідності $з$ періодичністю, визначеною статутом, але не рідше одного разу на квартал (абз. 4 ч. 1 ст. 55 Закону України «Про акціонерні товариства»). Засідання наглядової ради можуть проводитись шляхом заочного голосування (опитування) (абз. 5 ч. 1 ст. 55 Закону України «Про акціонерні товариства»), а повний та своєчасний обмін інформацією між членами наглядової ради, виконавчим органом товариства може забезпечуватися секретарем наглядової ради або корпоративним секретарем товариства.

Обрання до наглядових рад та участь у них іноземців здійснюється на конкурсних засадах у порядку, визначеному постановою Кабінету Міністрів України від 10 березня 2017 р. № 142. Оскільки членство в наглядових радах не є державною службою, у конкурсному відборі мають переважати професійні критерії, такі як освіта, досвід роботи, професійні навички у суб'єктах корпоративного типу відповідної галузі економіки, особисті якості кандидата.

До складу наглядових рад обираються члени (акціонери та їхні представники, представники уповноважених органів) та незалежні члени (незалежні директори). Іноземні громадяни та особи без громадянства мають право нарівні з громадянами України брати участь у конкурсі, але виключно на посади незалежних членів наглядової ради.

Водночас призначення до складу наглядових рад іноземних громадян та осіб без громадянства створює ризик та може завдати шкоди національним інтересам України в інформаційній сфері, якими відповідно до Закону України від 21 червня 2018 року «Про національну безпеку України», Доктрини інформаційної безпеки України, затвердженої Указом Президента України від 25 лютого 2017 року № 47/2017, Стратегії національної безпеки України, затвердженої Указом Президента України від 14 вересня 2020 року № 392/2020, є захищеність державної таємниці, конфіденційної інформації, комерційної таємниці та іншої інформації, вимоги щодо захисту якої встановлені законом. Відповідно до ч. 2 ст. $11^{4}$ Закону України «Про управління об'єктами державної власності» керівник державного унітарного підприємства забезпечує членам наглядової ради доступ до інформації в межах, передбачених законом та статутом державного підприємства.

Цей ризик може бути знижений шляхом включення до умов цивільно-правового договору, що укладається 3 незалежними членами наглядової ради, зобов'язань про збереження конфіденційної інформації та комерційної таємниці та реалізації інституту відповідальності за їх розголошення.

Ч. 2 ст. 38 Конституції України визначає, що громадяни користуються рівним правом доступу до державної служби, а також до служби в органах місцевого самоврядування.

Визначення поняття «державна служба» містить ст. 1 Закону України «Про державну службу», яка визначає іï як публічну, професійну, політично неупереджену діяльність із практичного виконання завдань і функцій держави, зокрема, у сферах, визначених цим законом.

Державний службовець - це громадянин України, який займає посаду державної служби в органі державної влади, іншому державному органі, його апараті (секретаріаті), одержує заробітну плату за рахунок коштів державного бюджету та здійснює встановлені для цієї посади повноваження, безпосередньо пов'язані 3 виконанням завдань i функцій такого державного органу, а також дотримується принципів державної служби.

Державні органи у своїй сукупності утворюють державний апарат, який є складовою частиною механізму держави, до якого також входять державні установи, державні організації та державні підприємства. Останні, на відміну від державного органу, не мають державно-владних повноважень; не виступають від імені держави; виступають частиною механізму, а не апарату держави; мають певні права і обов'язки щодо створення матеріальних і духовних благ, а не компетенцію щодо реалізації функцій держави. Наявність державно-владних повноважень $є$ найбільш важливою характеристикою органів державної влади, а також ознакою, що дозволяє відмежувати органи державної влади від інших суб'єктів [3, с. 28].

Конституцією та законами України для посадових і службових осіб органів державної влади та органів місцевого самоврядування встановлені певні правила поведінки, у тому числі й окремі обмеження щодо їхньої позаслужбової діяльності (ч. 2 ст. 42, ч. 2, 3 
ст. 78 , ч. 4 ст. 103 , ч. 1 ст. 120 , ч. 2 ст. 127 Конституції України). Особи, уповноважені на виконання функцій держави та місцевого самоврядування, зобов'язані вживати заходів щодо недопущення будь-якої можливості виникнення конфлікту інтересів.

Положеннями Закону України «Про запобігання корупції» від 14 жовтня 2014 року № 1700-VII прирівнюються до осіб, уповноважених на виконання функцій держави або місцевого самоврядування:

a) посадові особи юридичних осіб публічного права, які не зазначені у пункті 1 частини першої цієї статті, члени Ради Національного банку України (крім Голови Національного банку України), особи, які входять до складу наглядової ради державного банку, державного підприємства або державної організації, що має на меті одержання прибутку, господарського товариства, у статутному капіталі якого більше 50 відсотків акцій (часток) належать державі (Підпункт «а» пункту 2 частини першої статті 3 Закону «Про запобігання корупції»).

Особам, зазначеним у пункті 1 частини першої статті 3 Закону, забороняється входити до складу правління, інших виконавчих чи контрольних органів, наглядової ради підприємства або організації, що має на меті одержання прибутку (крім випадків, коли особи здійснюють функції з управління акціями (частками, паями), що належать державі чи територіальній громаді, та представляють інтереси держави чи територіальної громади в раді (спостережній раді), ревізійній комісії господарської організації), якщо інше не передбачено Конституцією або законами України (ст. 25 Закону України «Про запобігання корупції»). Вказані обмеження визнано конституційними Конституційним Судом України в рішенні від 13 березня 2012 р. у справі № 6-рп/2012 за конституційним поданням 53 народних депутатів України щодо відповідності Конституції України (конституційності) п. 2 ч. 1 ст. 7, п. 2 розд. VIII «Прикінцеві та перехідні положення» Закону України «Про засади запобігання і протидії корупції», за винятком встановлення заборони вказаним особам брати участь у загальних зборах такого підприємства або організації.

Водночас наглядова рада не є державним органом. Виконання функцій незалежного члена наглядової ради не є державною службою. На осіб, що обираються до складу наглядових рад (крім держслужбовців), не поширюється Закон України «Про державну службу». Наглядова рада $є$ колегіальним органом корпоративного управління, що в межах компетенції, визначеної стату- том, контролює та регулює діяльність виконавчого органу (керівника) (ч. 6 ст. 73 ГК України, ч. 1 ст. 51 Закону України «Про акціонерні товариства», ч. 2 ст. 38 Закону України «Про товариства 3 обмеженою та додатковою відповідальністю»), регулює діяльність товариства (ч. 1 ст. 51 Закону України «Про акціонерні товариства»), здійснює захист прав акціонерів товариства (ч. 1 ст. 51 Закону України «Про акціонерні товариства»). Члени наглядової ради не є особами, уповноваженими на виконання функцій держави або місцевого самоврядування. Члени наглядової ради $є$ посадовими особами державного унітарного підприємства, господарського товариства (ч. 2 ст. 65 Господарського кодексу України, п. 15 ч. 1 ст. 2 Закону України «Про акціонерні товариства», ч. 1 ст. 42 Закону України «Про товариства 3 обмеженою та додатковою відповідальністю»).

Відповідно до ч. 12, 13 ст. 11 Закону України «Про управління об'єктами державної власності» у разі якщо корпоративні права держави перевищують 25 відсотків статутного капіталу господарської організації, до складу наглядової ради та ревізійної комісії обов'язково включається представник Фонду державного майна України або уповноваженого органу управління. Головою наглядової ради господарської організації, у статутному капіталі якої корпоративні права держави перевищують 50 відсотків, обирається будь-який член наглядової ради.

Відповідно до ч. 2 ст. 14 Закону України «Про управління об'єктами державної власності» члени наглядових рад мають право на оплату своєї діяльності та компенсацію витрат, пов'язаних з виконанням своїх функцій, за рахунок такого державного унітарного підприємства або господарського товариства. Порядок визначення умов оплати послуг членів наглядових рад встановлюється постановою Кабінету Міністрів України від 4 липня 2017 р. № 668 «Про затвердження Порядку визначення умов оплати послуг та компенсації витрат членів наглядових рад державних унітарних підприємств та господарських товариств, у статутному капіталі яких більше 50 відсотків акцій (часток) належать державі».

Дія Порядку не поширюється на членів наглядових рад, які займають посади державної служби, інші посади осіб, уповноважених на виконання функцій держави або місцевого самоврядування, визначених у пункті 1 частини першої статті 3 Закону України «Про запобігання корупції».

Суб'єкт управління об’єктами державної власності, до сфери управління якого нале- 
жить підприємство, загальні збори товариства приймають рішення про розмір річної винагороди членам наглядової ради 3 урахуванням показників визначення розміру винагороди членів наглядових рад підприємства, товариства, визначених у додатку до постанови Кабінету Міністрів України від 4 липня 2017 р. № 668.

Показники визначення розміру винагороди членів наглядових рад збільшуються залежно від чистого річного доходу від реалізації продукції (товарів, робіт, послуг) підприємства, товариства за даними останньої річної фінансової звітності. При цьому розмір місячної винагороди оплати послуг члена наглядової ради визначається у кратності (від 5 до 22) до середньомісячної заробітної плати за видами економічної діяльності за квартал у середньому по економіці, що передує кварталу розрахунку розмірів винагороди оплати послуг членів наглядової ради, за опублікованими статистичними даними Держстату.

Суб'єкт управління об'єктами державної власності, до сфери управління якого належить підприємство, загальні збори товариства щороку переглядають розмір річної винагороди членам наглядової ради, можуть прийняти рішення про виплату додаткової винагороди членам наглядової ради. Сума річної та додаткової винагород члену наглядової ради за виконання ним своїх функцій зазначається у цивільно-правовому договорі між членом наглядової ради та підприємством, товариством.

Отже, дохід незалежного члена наглядової ради складається з базової річної винагороди, яка залежить від розміру чистого річного доходу підприємства, додаткової винагороди та компенсації витрат на проїзд, проживання у готелі протягом часу участі у засіданнях наглядової ради, інших обгрунтованих витрат, які пов'язані з виконанням ним своїх функцій. Середній розмір винагороди членів наглядових рад у більшості державних підприємств становить близько 100 тисяч гривень на місяць, але у стратегічних компаніях, таких як НАК «Нафтогаз України» та АТ «Укрзалізниця», винагорода може бути більшою, оскільки їхні фінансові показники становлять сотні мільярдів гривень [4].

Аналіз вищезазначених положень свідчить, що розмір винагороди пов'язаний 3 кратністю до середньомісячної заробітної плати за видами економічної діяльності за квартал у середньому по економіці і прямо не пов'язаний із чистим прибутком відповідного підприємства, товариства; кратність $є$ істотно завищеною (від 5 до 22); не обме- жений максимальним розміром (в еквіваленті в грн.) і не враховує неповну занятість членів наглядової ради та той факт, що член наглядової ради може одночасно бути членом наглядових рад кількох юридичних осіб (не більше ніж п'яти юридичних осіб) (постанова КМУ від 10.03.2017 р. № 142).

Розмір винагороди членів наглядових рад має визначатись у відсотках від чистого прибутку суб'єкта господарювання за попередній звітній період (рік), оцінки ефективності діяльності наглядової ради в цілому, iï комітетів і кожного члена наглядової ради, що стимулюватиме, завдяки управлінським рішенням членів наглядової ради, підвищення фінансово-економічних показників таких суб'єктів, належне виконання обов'язків членами наглядової ради. При цьому розмір відсотку має залежати від галузі економіки та фінансово-економічного стану суб'єкта господарювання.

Компенсації підлягають також витрати членів наглядових рад, пов'язані з виконанням ними своїх функцій, за умови їх документального підтвердження. До витрат, які компенсуються, належать, зокрема, витрати на проїзд; витрати на проживання у готелі протягом часу участі у засіданнях наглядової ради, витрати, пов'язані з отриманням віз до інших країн (якщо поїздки за кордон необхідні у зв'язку з виконанням функцій члена наглядової ради); інші обгрунтовані витрати члена наглядової ради, які пов'язані з виконанням ним своїх функцій. Участь іноземців у складі наглядової ради зумовлює додаткові витрати підприємств та господарських товариств, пов'язані з компенсацією окреслених витрат. Вважаємо, що умови цивільно-правового договору, що укладається з незалежним членом наглядової ради, обов'язково повинні містити обмеження щодо компенсації вищезгаданих витрат.

На жаль, ті сподівання, які покладав законодавець на запровадження наглядових рад у підприємствах державного сектора економіки, наразі не реалізувались, і незалежні члени наглядових рад не змогли зробити державні підприємства більш ефективнішими та прибутковими.

Нині на розгляді Верховної Ради України знаходиться законопроєкт «Про внесення змін до деяких законодавчих актів щодо забезпечення рівних прав та можливостей громадян із представництва у наглядових радах та органах правління державних унітарних підприємств, господарських товариств та державних банків та справедливого формування і ефективної діяльності таких наглядових рад із врахуванням національних інтересів України» № 3193-1 від 17.03.2020 р. 
Згаданий проєкт встановлює принцип, відповідно до якого у наглядових радах державних унітарних підприємств, господарських товариств та державних банків можуть бути представлені виключно громадяни України, які є професіоналами у відповідній сфері та не залежать від тих чи інших громадських об'єднань.

Законопроект забороняє самим державним унітарним підприємствам, господарським товариствам та державним банкам здійснювати виплати винагород членам наглядових рад. Ця функція покладається виключно на Кабінет Міністрів України. Також передбачається законодавче обмеження розміру оплати праці членів наглядових рад. Зокрема, максимальний місячний розмір оплати їхніх послуг (враховуючи заробітну плату, будь-які надбавки, премії, заохочувальні виплати, компенсацію витрат, пов'язаних з виконанням їхніх функцій) не може перевищувати 50 прожиткових мінімумів, встановлених для працездатних осіб на 1 січня відповідного року.

Комітет Верховної Ради України з питань інтеграції України з Європейським Союзом у своєму висновку зазначив, що положення проєкту Закону «Про встановлення максимального місячного розміру оплати послуг членів наглядових рад» частково враховують Принципи ОЕСР щодо корпоративного врядування на підприємствах державної форми власності, якими передбачено, що для підприємств державної форми власності, що мають переважно цілі господарського характеру та працюють в конкурентному середовищі, необхідно, щоб рівні винагороди праці членів наглядових рад відображали наявні ринкові умови з метою залучати й утримувати на посаді кваліфікованих членів наглядової ради.

Комітет Верховної Ради України з питань бюджету на засіданні 25 листопада 2020 року розглянув проєкт та повідомив, що згідно з експертним висновком Міністерства фінансів України реалізація положень законопроєкту може призвести до додаткових витрат з державного бюджету на виплати членам наглядових рад державних унітарних підприємств та господарських товариств, проте оцінити вплив законопроєкту на показники бюджету неможливо через відсутність необхідних для розрахунку даних. При цьому Міністерство фінансів України зазначає, що положення законопроєкту щодо здійснення виплат виключно Кабінетом Міністрів України не містять механізму реалізації, що при- зведе до неможливості їі практичного застосування. Загалом Мінфін надає зауваження до положень законопроекту та не підтримує його у запропонованій редакції.

\section{Висновки}

Враховуючи вищенаведене, можна зробити висновок, що іноземні громадяни та особи без громадянства мають право нарівні з громадянами України брати участь у конкурсі, але виключно на посади незалежних членів наглядової ради. Оскільки членство в наглядових радах не є державною службою, у конкурсному відборі таких осіб мають переважати професійні критерії, такі як освіта, досвід роботи та професійні навички у суб'єктах господарювання корпоративного типу відповідної галузі економіки, а також особисті якості кандидата.

Розмір винагороди членів наглядових рад має визначатись у відсотках від чистого прибутку суб'єкта господарювання за попередній звітній період (рік), оцінки ефективності діяльності наглядової ради в цілому, її комітетів і кожного члена наглядової ради, що стимулюватиме, завдяки управлінським рішенням членів наглядової ради, підвищення фінансово-економічних показників таких суб'єктів, належне виконання обов'язків членами наглядової ради. При цьому розмір відсотку має залежати від галузі економіки та фінансово-економічного стану суб'єкта господарювання. Максимальний розмір винагороди має бути обмежено законом. Умови договору з незалежним членом наглядової ради обов'язково повинні містити обмеження щодо компенсації витрат, пов'язаних $з$ виконанням його обов'язків.

\section{Список використаних джерел:}

1. Мягкий А. В. Корпоративне управління за законодавством України : дис. ... канд. юрид. наук: 12.00.04. Київ, 2017. 225 с

2. Чи можуть іноземні громадяни брати участь у роботі наглядових рад наших природних держмонополій? URL: https://ua.112.ua/mnenie/ prodaty-vse-z-molotka--tse-bozhevillia-z-chym-mytodi-zalyshymosia-542374.html (дата звернення: 01.11.2020).

3. Органи державної влади в Україні: структура, функції й тенденції розвитку : навчальний посібник / заг. ред. Н.Р. Нижник. К. : НІЧЛАВА ; Івано-Франківськ, 2003. 284 с.

4. Дуже секретні зарплати. URL: https:// www.epravda.com.ua/rus/publications/2020/02 (дата звернення: 01.11.2020). 
Oleksandra Kolohoida, Olena Chernenko. Legal status of independent members of the supervisory councils of state enterprises

The article is devoted to the issues of the state enterprises supervisory boards independent members legal status. The creation of a supervisory board as a control body designed to protect the company owners interests, recognized as appropriate in many countries around the world. Supervisory boards in the system of the state unitary enterprises governing bodies make it possible to involve professional and independent specialists in the management, in order to increase the economic results of public sector entities.

Institutional and qualification requirements to the supervisory boards members and independent members do not require Ukrainian citizenship for a person to be appointed (elected) to the supervisory board independent member position. Foreign citizens and stateless persons have the right to participate in the competition on an equal footing with Ukrainian citizens, but only for the positions of the supervisory board independent members. Supervisory boards membership is not a public service, so the competitive selection of such persons should be dominated by professional criteria such as education, work experience and professional skills in business entities of the economy relevant sector, as well as the personal qualities of the candidate.

The appointment of foreigners as a supervisory boards independent members is due to the lack of the required level specialists in Ukraine and the fact that foreigners are more independent of the various political forces influence. Today, foreigners make up the majority in the supervisory boards of state-owned enterprises. However, the appointment of foreigners to supervisory boards poses a risk and may harm Ukraine's national information interests, so the agreement with the supervisory board independent member should include obligations to maintain confidential information and trade secrets and the responsibility for its disclosure.

The supervisory boards independent members reward payment should be determined as a percentage of the previous reporting period (year) entity net profit, evaluation of the supervisory board efficiency as a whole, its committees and of the supervisory board each member. This interest rate should depend on economics and entity financial position. The maximum of reward payment compensation must be limited by law. The supervisory board independent member contract terms should contain the limited reimbursement of expenses related to the performance of his duties.

Key words: state enterprise, corporate governance, supervisory board, supervisory board independent members. 